\title{
Quality Evaluation of Wine Produced from Tiger Nut (Cyperus esculentus L.) Drink
}

\author{
Eke-Ejiofor J*, Nnodim L. C \\ Department of Food Science and Technology, Rivers State University, Port Harcourt, Nigeria \\ *Corresponding author: joyekee@yahoo.co.uk \\ Received April 04, 2019; Revised May 11, 2019; Accepted May 28, 2019
}

\begin{abstract}
Tigernut drink is faced with the challenge of short shelf-life, which has affected its use for different nutritious drinks, therefore fermentation process which is a form of food preservation technology for limiting or reducing post-harvest wastage associated with tiger nuts usage at harvest, could help to convert it into wine. Must (the first step in wine making) was prepared from dried and fresh tigernut filtrate blended with zobo flower extract, with inoculum developed from commercial wine yeast. Fermentation of dried and fresh tigernut must were carried out over a period of seven (7) days, while microbial, physicochemical and sensory properties of the blends were also analyzed. Dried and fresh tiger nut wines were compared with commercial grape wine as control. The inoculum developed, had a yeast count of $10^{8}$ and $10 \%$ of must volume. The initial $\mathrm{pH}$ of dried and fresh tigernut musts were 4.50 and 4.20 , which decreased to 3.00 for both dried and fresh tigernut wine, while the initial titratable acidity of dried and fresh tigernut must were 0.0023 and 0.0024 (\%) and increased to 0.016 and 0.021 (\%) respectively. The sugar content of the must decreased from 17 and 14 (\%) for dried and fresh tigernut to 5 (\%) for both tigernut wine respectively, while the specific gravity of the tigernut musts were 1.070 and 1.060 for dried and fresh tigernut must and 0.705 for dried and fresh tigernut wine. Dried tigernut wine had alcohol content of $8.19 \%(\mathrm{v} / \mathrm{v})$, while fresh tigernut wine had a value of $6.41 \%(\mathrm{v} / \mathrm{v})$. The microbial count of dried tigernut must before fermentation were as follows, otal acterial ount $6.61 \log _{10} \mathrm{CFU} / \mathrm{ml}$ and Total Yeast Count $8.34 \log _{10} \mathrm{CFU} / \mathrm{ml}$, while fresh tiger nut must before fermentation had Total Bacterial Count of $6.59 \log _{10} \mathrm{CFU} / \mathrm{ml}$ and Total Yeast Cells of $8.30 \mathrm{Log}_{10} \mathrm{CFU} / \mathrm{ml}$. At the end of fermentation period (7 days), total bacterial count was $1 \log _{10} \mathrm{CfU} / \mathrm{ml}$; total yeast count was 9.99 $\log _{10} \mathrm{CFU} / \mathrm{ml}$ for dried tiger nut, while fresh tiger nut had bacterial count of $1.3 \log _{10} \mathrm{CFU} / \mathrm{ml}$ and yeast count of 9.99 $\log _{10} \mathrm{CFU} / \mathrm{ml}$ respectively. There was no significant $(\mathrm{p}>0.05)$ difference between the dried tiger nut wine and grape wine, but significant $(\mathrm{p}<0.05)$ difference existed between the fresh tigernut wine and the grape wine which was used as control.
\end{abstract}

Keywords: fermentation, tigernut, zobo plant, wine, quality parameter

Cite This Article: Eke-Ejiofor J, and Nnodim L.C, "Quality Evaluation of Wine Produced from Tiger Nut (Cyperus esculentus L.) Drink.” American Journal of Food Science and Technology, vol. 7, no. 4 (2019): 113-121. doi: 10.12691/ajfst-7-4-2.

\section{Introduction}

Wines are alcoholic beverages produced by fermenting sugary juices; conventionally grape juice [1]. The characteristics of wines depend on the kind of fruit used, such as hard cider wine from apples, Perry wine from pears, Pomegranate wine from banana, blueberry and elderberry wines are from berry fruits [2]. Wines made from sugar cane [3], pawpaw and pineapple [4] and tuber extracts [5] have also been reported. Using fruits and vegetables with medicinal and nutritional value, for wine production can be improved [6], to possess typical wine components of ethyl alcohol, sugar, acids, higher alcohols, tannins, aldehydes, esters, amino acids, minerals, vitamins, anthocyanins and flavour compounds [7]. Wines can be grouped into, grape wine, fruit wine, berry wine, vegetable wine, and raisin wine [8]. Grape wine is made exclusively from grapes and other materials are prohibited as adjuncts (except for sugar and oak barrels). Fruit wines are alcoholic beverages made from a variety of base ingredients like fruits, flowers, or herbs. Multi sort wine is produced by mixing different kinds of grapes and wine materials [8].

Tigernuts (Cyperusesculentus L.) are tubers found on the root of sedge plant. It is a perenial grass-like plant with spheriod tubers, pale yellow cream kernel surrounded by a fibrous sheath [9]. Nigeria has three varieties: black, brown and yellow, but only the brown and yellow are readily available in markets. The yellow tigernut is preferred for its bigger size, attractive colour, fleshier body and yield of more milk which contains lower fat, higher protein and less anti-nutritional factors especially polyphenols [10]. Tiger nut can be eaten raw, roasted, dried, baked or made in to a refreshing drink which has a short shelf life and so a major setback to its commercialization. FAO [11] and TTSL [9] showed that 
tigernut tubers are rich in starch (20-30\% of dry weight) and fat $(20-28 \%$ DW) with small quantities of protein which is about twice that of cassava. Total sugar content, reducing sugar and sucrose content are high [12] and also contain phosphorus, potassium, magnesium, calcium, zinc, copper, sodium, manganese [9] and with a sweet nutty flavour [13] which makes it suitable for wine production.

The plant, Hibiscus sabdariffa (zobo plant) is cultivated in northern Nigeria [14,15]. Many parts of roselle including seeds, leaves, fruits, flower and roots are used in the preparation of various foods. Among them, the fleshy red calyces are the most popularly [16] used for preparation of beverage (non-alcoholic) making juice, wine, herbal tea and as colouring agent for jelly, jam, beverages and foods [17] and traditional medicine [18,19]. The calyces extract is a health-enhancing drink due to its high content of vitamin $\mathrm{C}$, anthocyanins and other antioxidants [20] and phenolic compounds [21]. Dried zobo calyces contain flavonoids gossypetin, hibiscetine, sabdaretine daphniphylline, delphinidin 3-monoglucoside, cyaniding-3-monoglucoside (chrysanthemin) and delphinidin 22]. Despite intensified health campaigns against the misuse of alcoholic beverages in Nigeria, roselle drink has great potential to provide a healthy drink and a local alternative to imported red wine in particular and alcoholic beverage in general [23].

Fermentation is a relatively efficient, low energy preservation process which increases the shelf life, and decreases the need for refrigeration or other forms of food preservation technology. It is therefore an appropriate technique to handle the issue of high perishability and provide increased diversification. This study therefore is aimed at evaluating the quality of wine produced from blends of tiger nut/zobo extract.

\section{Materials and Methods}

\subsection{Materials}

Materials used for this study are fresh and dried yellow tigernut (Cyperus esculentus), granulated sugar, Zobo (Hibiscus sabdariffa) flower and commercial yeast, which were purchased from Mile 1 market, Port Harcourt, Rivers State, Nigeria

\subsection{Chemicals}

Chemicals such as Ammonium sulphate, Sodium Metabisulphite, Potassium hydrogen phosphate and commercial wine yeast used for this study were of analytical grade and were obtained from the analytical laboratory, Department of Food Science and Technology, Rivers State University, Nigeria.

\subsection{Methods}

\subsubsection{Preparation of Zobo Extract}

Zobo (Hibiscus sabdarifa) flower (100g) was boiled in $500 \mathrm{ml}$ of water for 30 minutes to increase extraction of the juice. Zobo extract was filtered and allowed to cool for further use.

\subsubsection{Preparation of Tiger Nut Extract}

The tiger nuts (fresh and dried) were washed and wet milled, using $2500 \mathrm{ml}$ water to $500 \mathrm{~g}$ of tiger nut. The mash was then filtered using muslin cloth to achieve maximum liquid extraction without solid particles.
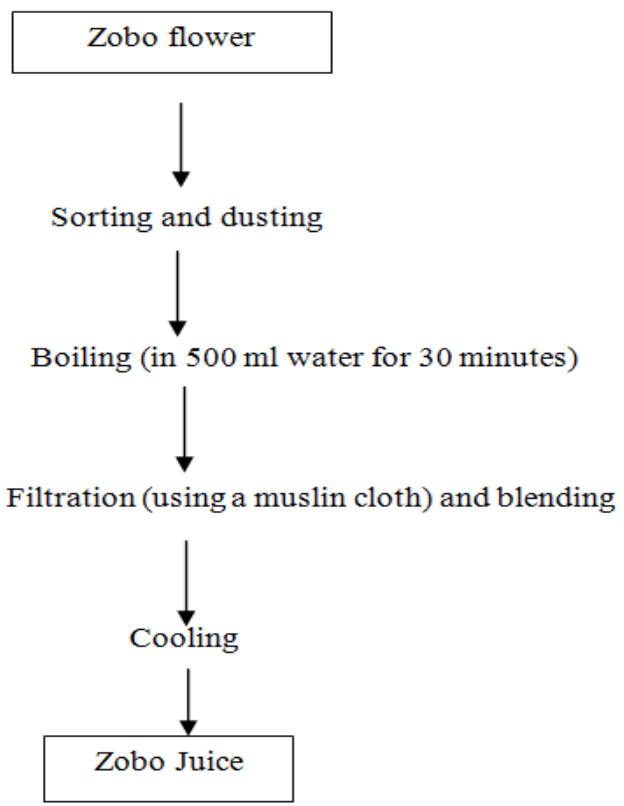

Figure 1. Flow chart for the production of zobo extract (Source: [24])

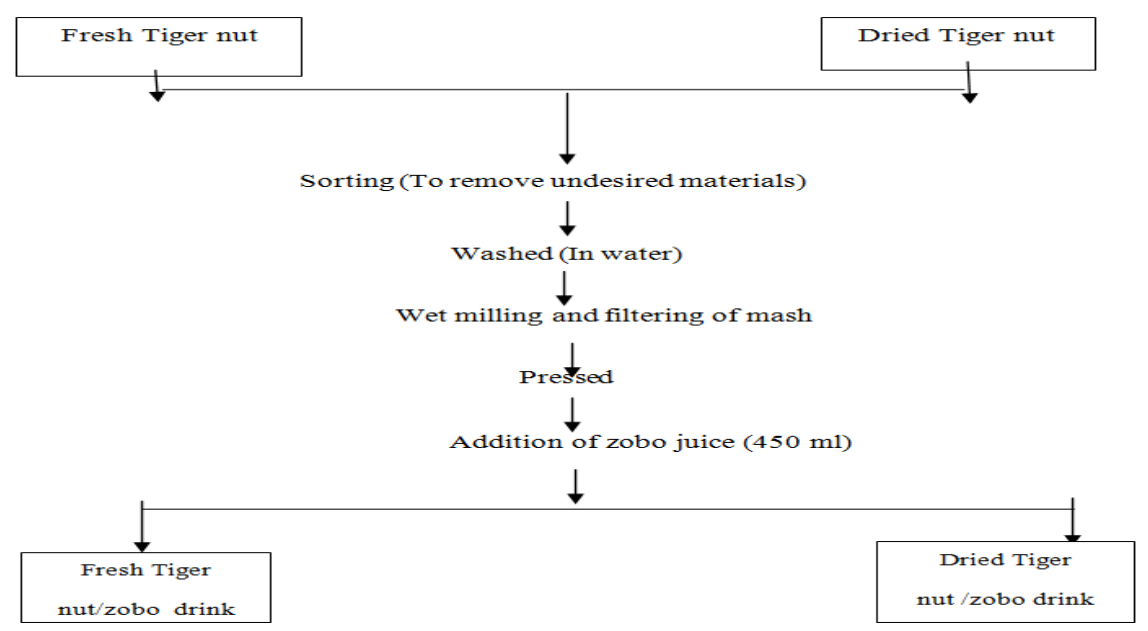

Figure 2. Flow process for the preparation of fresh and dried tiger nut milk extract enriched with zobo juice. Source: [25] 
Table 1. Recipe for wine production

\begin{tabular}{lll}
\hline Composition & Fresh Tiger nut & Dried Tiger nut \\
\hline Tiger nut (g) & 2550 & 2550 \\
Sugar (g) & 400 & 400 \\
Zobo drink (ml) & 450 & 450 \\
Yeast (ml) & 400 & 400 \\
Ammonium Phosphate & 2.52 & 2.52 \\
Potassium phosphate (g) & 3.6 & 3.6 \\
Yeast extract (g) & 1.0 & 1.0 \\
\hline
\end{tabular}

Source: [26].

\subsubsection{Chaptalization and Supplementation of the Must}

Chaptalization and supplementation of musts were according to the method of Amerine and Kunkee [26] as adopted by Robinson [27] was used. The must (fresh and dried tiger nut extract) were chaptalized with $200 \mathrm{~g} / \mathrm{l}$ of sugar. The sugar was dissolved and homogenized in the musts and musts enriched with $2.52 \mathrm{~g} / \mathrm{l}$ Ammonium sulphate, $1.0 \mathrm{~g} / \mathrm{l}$ yeast extract and $3.6 \mathrm{~g} / \mathrm{l}$ Potassium dihydrogen phosphate.

\subsubsection{Fermentation}

Ten percent $(10 \% \mathrm{v} / \mathrm{v})$ of wine yeast starter culture was added to $2550 \mathrm{ml}$ of the must in a fermentation vessel. After pitching the wine yeast, the must was aerated for 6 hours by shaking, using a shaker at room temperature. After aeration, anaerobic condition was created to commence alcoholic fermentation for a period of 7 days and then the wine was racked. It was observed that the sediment contained a large quantity of residual and unutilized starch.

\subsubsection{Clarification, Racking and Aging}

At the end of fermentation, the wine was racked into clean container and kept in the refrigerator at $4^{\circ} \mathrm{C}$ for aging and clarification. Racking was carried out monthly for a period of two months to clarify the wine.

\subsubsection{Chemical Analysis}

Determination of Total Titratable Acidity, Total Soluble Solid, Specific Gravity and $\mathrm{pH}$ were according to the method of AOAC [28].

Alcohol content: The alcohol content of the wine was determined using specific gravity as described by Ogu [29], and calculated as follows:

$$
\text { Percentage alcohol }=(\mathrm{IG}-\mathrm{FG}) \times 131.25
$$

Where:

$\mathrm{IG}=$ Initial Gravity of the sample

$\mathrm{FG}=$ Final Gravity of the sample.

\subsection{Microbiological Analysis}

The total heterotrophic bacteria and yeast count were carried out according to Harrigan [30] modified. Nutrient and Potato dextrose agar (PDA) were used for enumeration of total heterotrophic bacteria and yeast counts respectively. One $\mathrm{ml}$ of sample was diluted in $9 \mathrm{ml}$ sterile distilled water serially up to $10^{-6}$. One $\mathrm{ml}$ aliquot from a suitable dilution was transferred aseptically into nutrient agar and PDA. The inoculum was evenly spread and inverted plates were incubated for 48 hours at $30^{\circ} \mathrm{C}$. The total hetrotrophic bacteria and yeast count $(\mathrm{CFU} / \mathrm{ml})$ were determined using a colony counter. The total coliform test was carried out according to Cheesbrough [31], using MacConkey agar and incubated at $37^{\circ} \mathrm{C}$ for $48 \mathrm{~h}$.
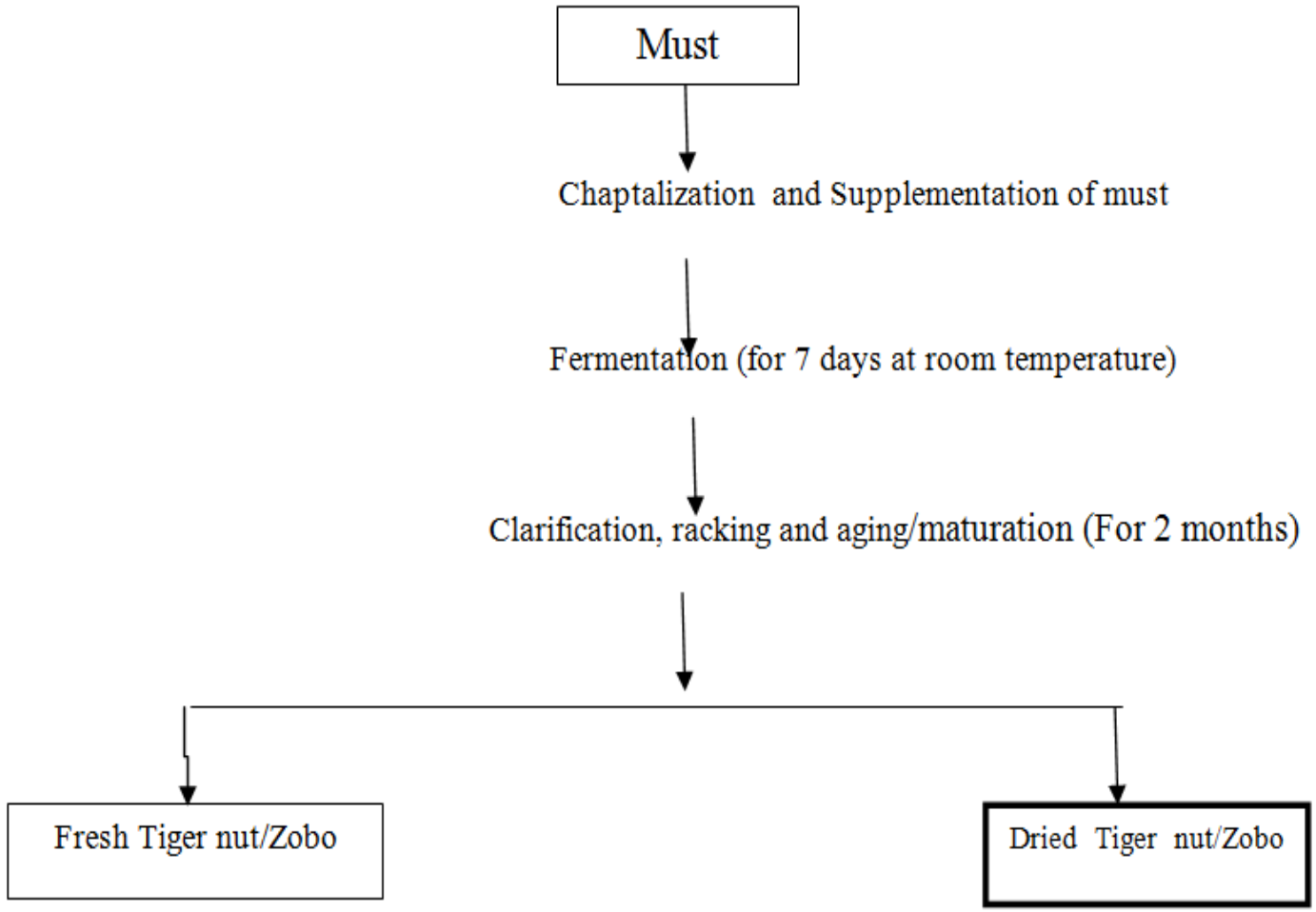

Figure 3. Flow process diagram for the production of Tiger nut wine (Source: [26]) 


\subsection{Sensory Evaluation}

The sensory evaluation of the wine was carried out by 20 semi trained panelists from the Department of Food Science and Technology, Rivers State University, who were neither sick nor allergic to any of the raw materials used for product development as at the time of the study. The panelists were presented with coded samples using transparent disposable cups and water for mouth rinsing after each tasting. Panelists were asked to score/evaluate the samples for taste, aroma, colour, clarity and overall acceptability using a 9-point hedonic scale where $9=$ Like Extremely and 1 dislike Extremely [32].

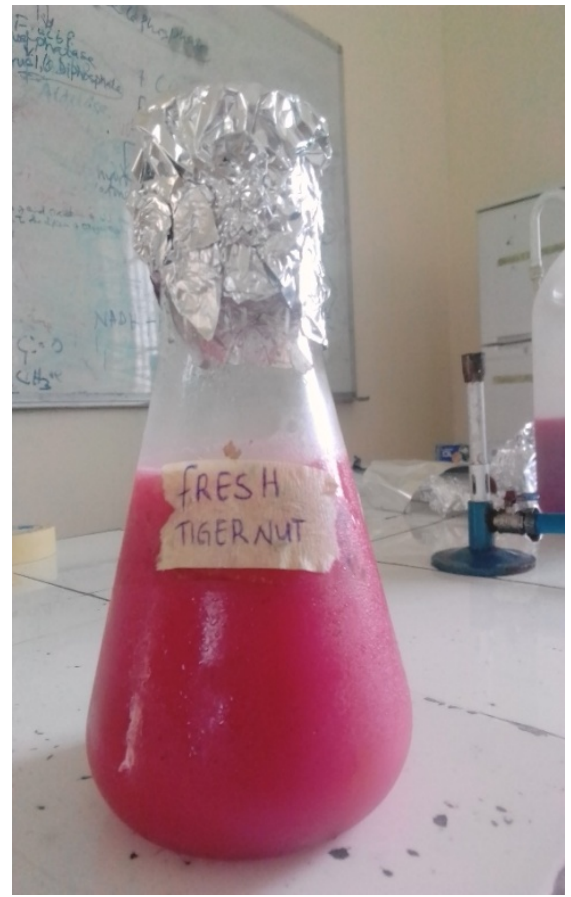

Plate 1. Fresh Tiger nut wine

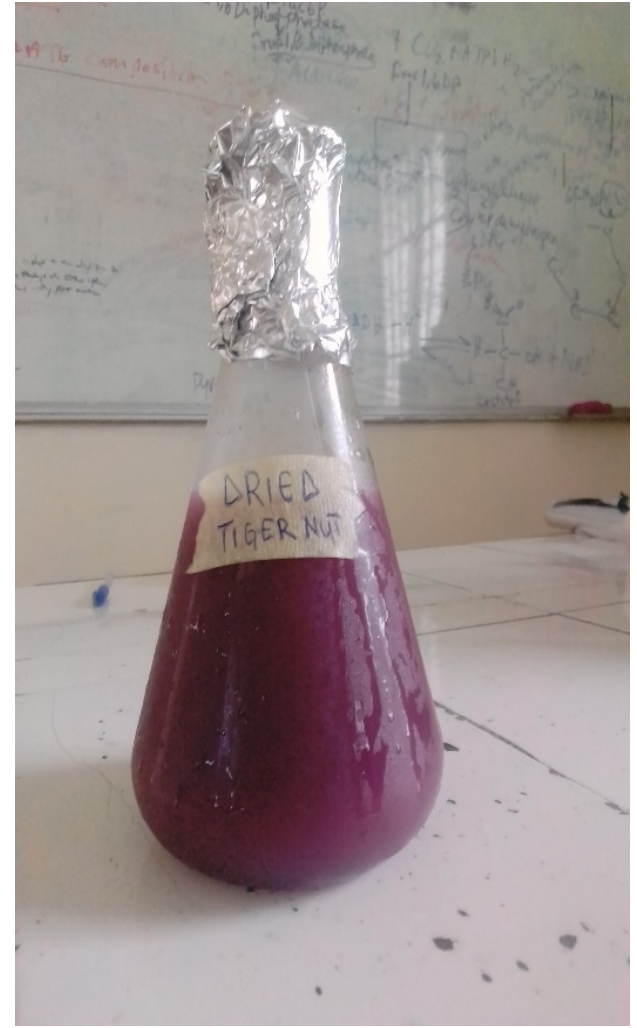

Plate 2. Dried Tiger nut wine

\section{Results and Discussions}

\subsection{Physicochemical Properties of Fresh and Dried Tiger Nut Must during Fermentation}

Changes in the $\mathrm{pH}$ of the fermenting tiger nut must during fermentation is shown in Figure 4.

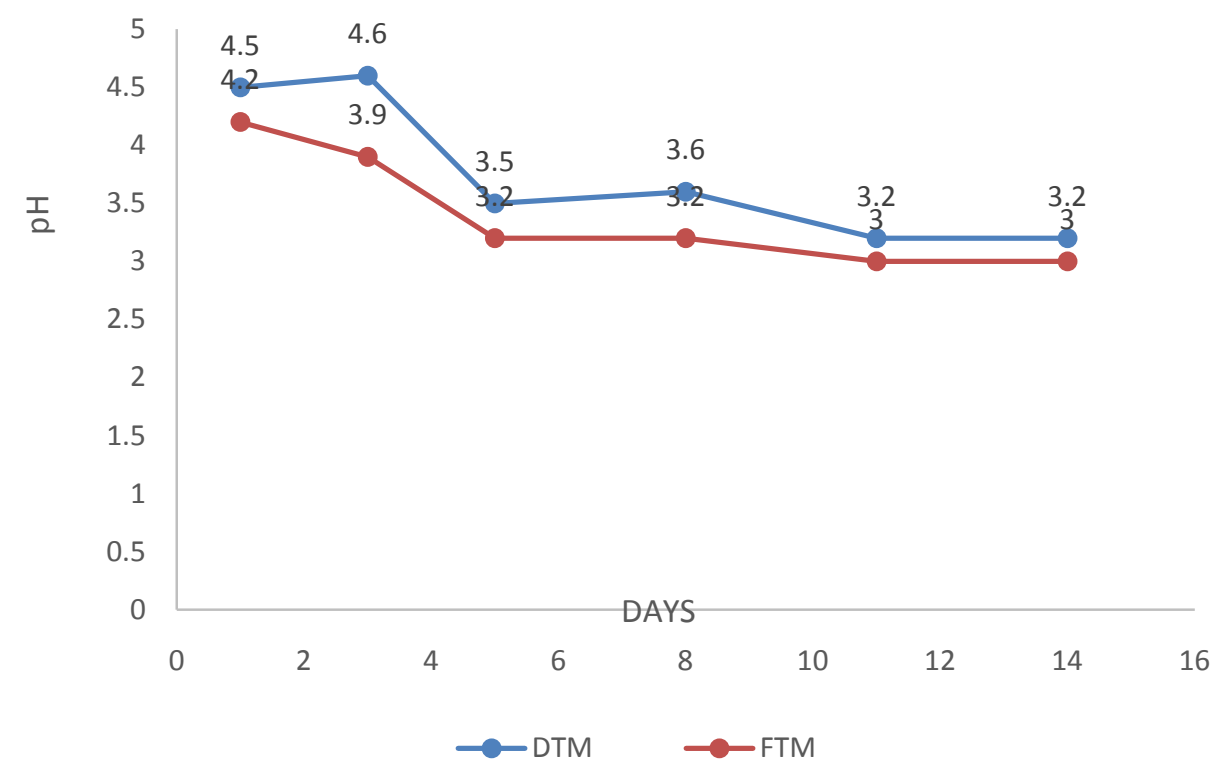

Figure 4. $\mathrm{pH}$ variations of fresh and dried tiger nut must during Fermentation (Keys: FTM=Fresh Tiger nut must, DTM= Dried Tiger nut must) 


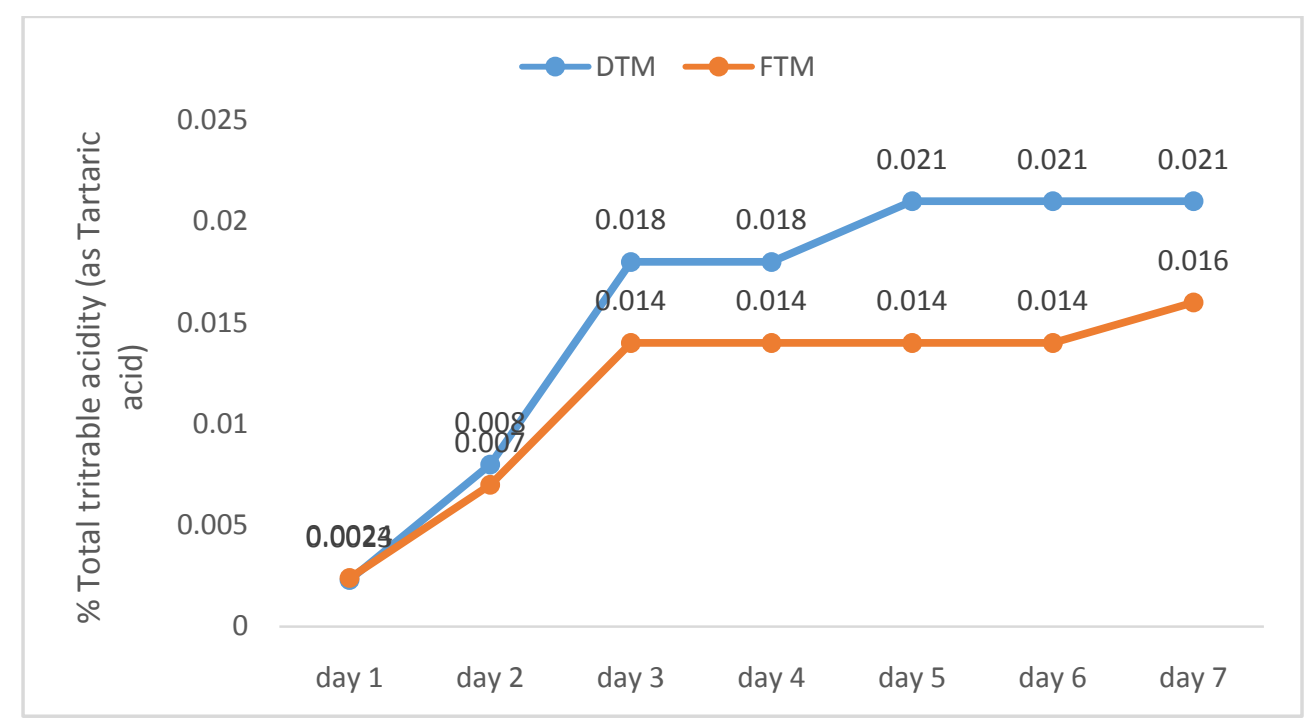

Figure 5. Changes in total titratable acidity of fresh and dried tigernut must during Fermentation (Keys: FTM=Fresh Tiger nut must, DTM= Dried Tiger nut must)

$\mathrm{pH}$ ranged from 4.50-3.20 for the dried tiger nut must and 4.20-3.00 for the fresh tiger nut must during primary fermentation. The results of physicochemical properties of fresh and dried tigernut must showed that there were change in $\mathrm{pH}$ from 4.50-3.20 and 4.20-3.00 for the fresh and dried tigernut must respectively after fermentation. All wines are acidic, usually between 3 and 4 with white wines being more acidic than red wine. $\mathrm{pH}$ have a major impact on the final product of wine as it could affect taste, smell and colour of wine. This is in agreement with the report of Fleet [33], who said that $\mathrm{pH}$ directly affects wine stability, as $\mathrm{pH}$ below 3.5 eliminates most of the microbes and favour, with only a few of the microorganisms for fermentation. $\mathrm{pH}$ of wine in the range of 3.5-3.8 suggest that an acidic $\mathrm{f}$ as well as alcoholic fermentation is taking place at the same time.

Figure 5 shows the trend in total titratable acidity (TTA). Titratable acidity was observed to range from $0.0014-0.023 \%$ over the period of fermentation for dried tiger nut must while fresh tiger nut must had titratable acidity ranging from $0.0021-0.024 \%$. Total titratable acidity (TTA) increased from $0.0023-0.016 \%$ for dried and $0.0024-0.021 \%$ for fresh tiger nut must after fermentation. This is in agreement with a study conducted by Reddy and Reddy [34], Abbo et al. [35], Bisson and Butzkc [36] and Ndubuisi [37]. However, low total titrable acidity have been the major problem associated with making non-grape wine [38].

Figure 6 shows the variation in the \%Sugar content of the must during the fermentation process, which decreased from $17-5 \%$ and $14-5 \%$ for dried and fresh tiger nut must respectively. Variation in sugar content of tigernut must at the initial stage of fermentation may be attributed to the processing treatment as drying has an effect on the sugar content of fruit juices [39]. During drying process, fructose, glucose and maltose significantly increases possibly due to milliard reaction [40]. According to Keller [41], sugar is the main substrate for fermentation of fruit juices into alcohol, although other food nutrients such as protein and fat can be broken down by some microorganisms in cases where sugar is limited.

During fermentation of the must in the present study, sugar content decreased from 17-5 (\%) for the dried tigernut must and 14-5 (\%) for fresh tigernut must, which agrees with the report that sugars were utilized for alcohol and organic acid production [42], since the total sugar content of tigernut wines were not more than $9 \%$, it implies that it is a table wine [8].

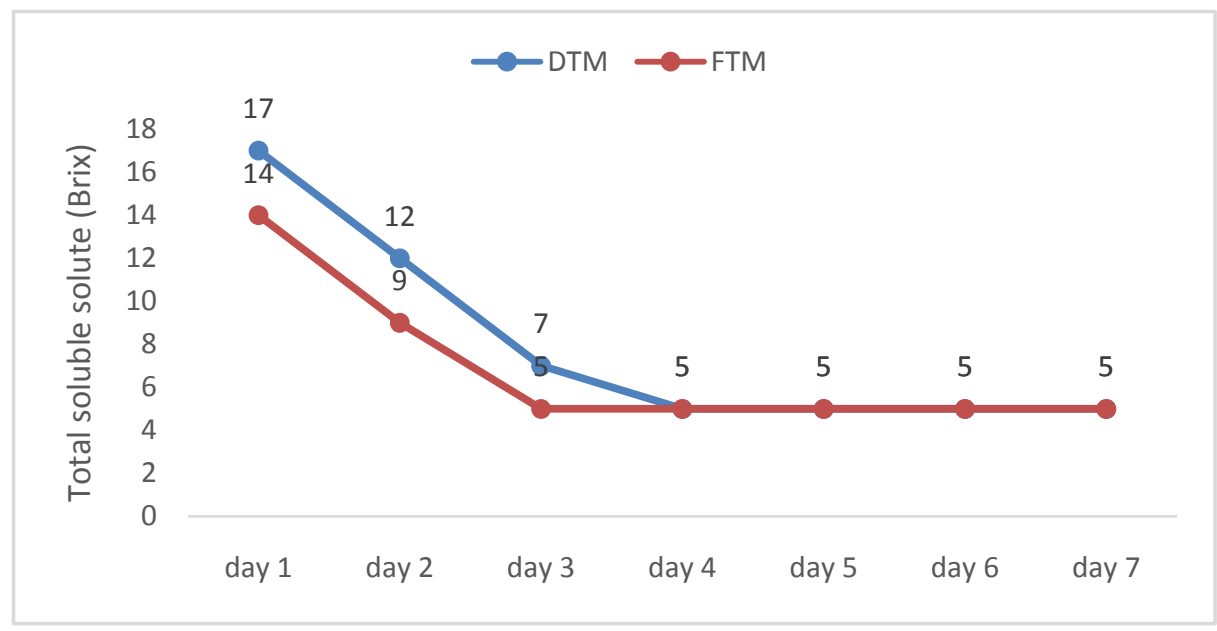

Figure 6. Changes in the sugar content (measured as total soluble solute) of fresh and dried tiger nut must during Fermentation (Keys: FTM=Fresh Tiger nut must, DTM= Dried Tiger nut must) 


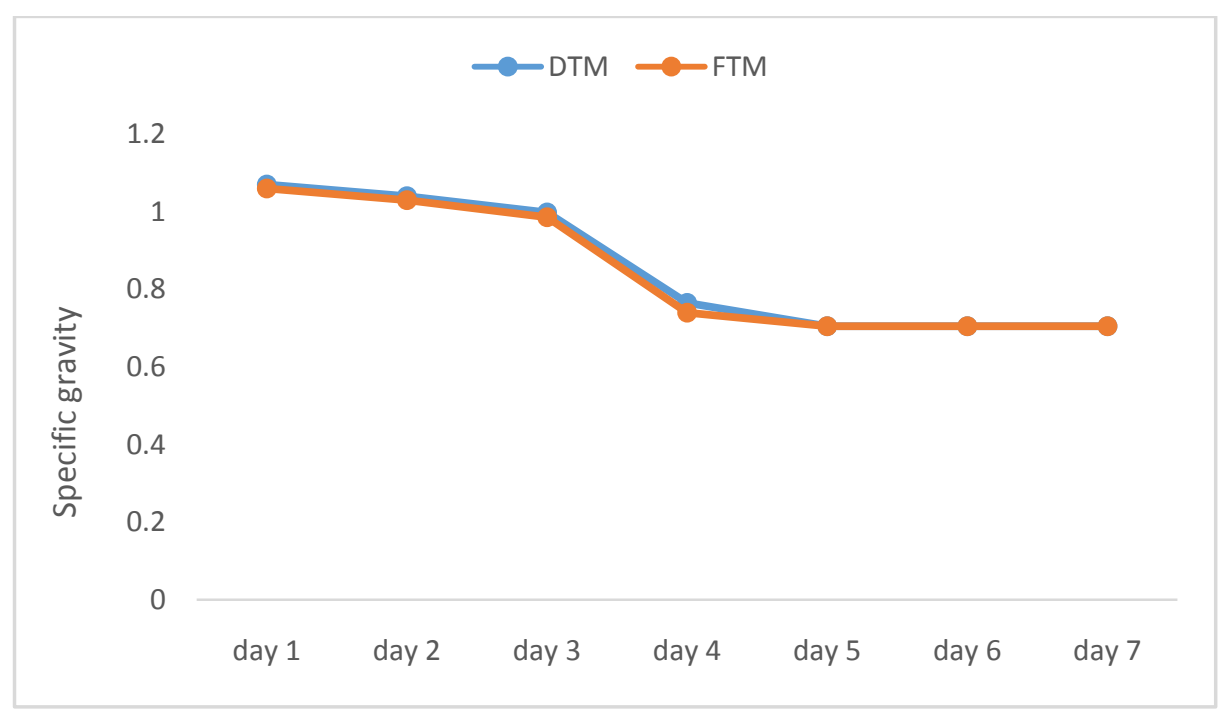

Figure 7. Changes in the specific gravity of fresh and dried tiger nut must during Fermentation (Keys: FTM=Fresh Tiger nut must, DTM= Dried Tiger nut must)

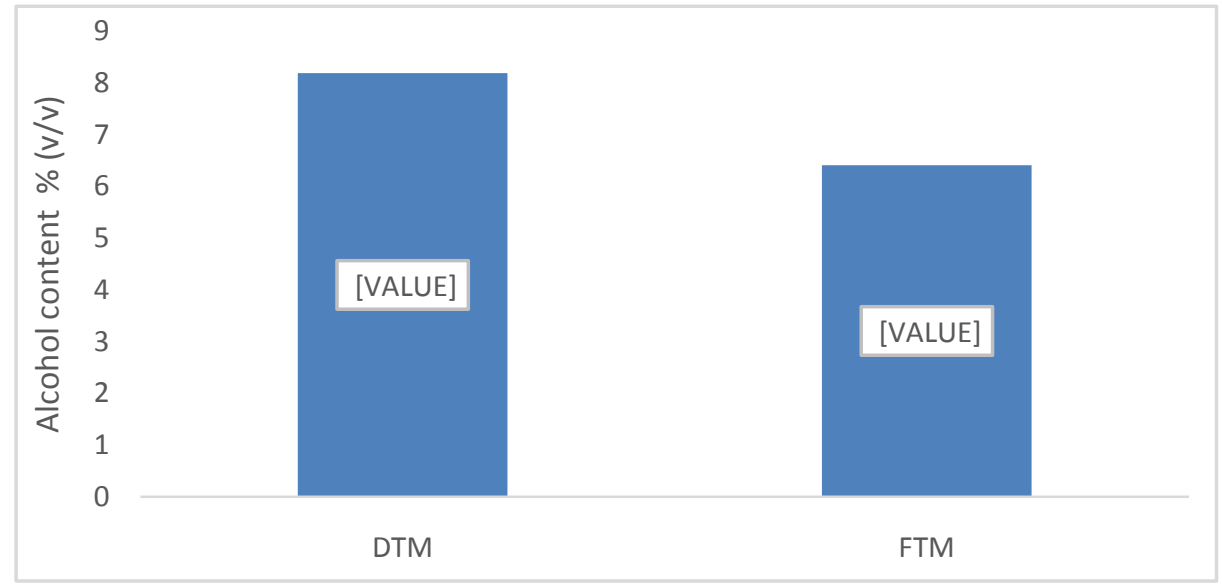

Figure 8. Alcohol content of dried and fresh tigernut wine after Fermentation (Keys: FTM=Fresh Tigernut wine, DTM= Dried Tigernut wine)

Changes in the specific gravity of the fermenting tiger nut must during fermentation is shown in Figure 7. Specific gravity of the tiger nut must range from 1.07-1.02 for dried tiger nut and $1.06-1.01$ for fresh tiger nut respectively. The specific gravity value of the wines obtained was is 0.705 for both fresh and dried tigernut wine, which falls within the 1.000 and 0.990 range for wine [43].

Figure 8 shows the alcohol content of fermented fresh and dried tiger nut wine. Alcohol content of the wines were $6.41 \%(\mathrm{v} / \mathrm{v})$ for fresh tiger nut and $8.19 \%(\mathrm{v} / \mathrm{v})$ for dried tiger nut respectively, which is in agreement with Shrinkant et al. [8] who reported an alcohol content above $2 \%$ for tiger nut wines, which is comparable with moderate grape wines. The low alcohol content observed in this study may be as a result of the large quantity of unutilized starch residue which could further be hydrolyzed to simpler sugars for increased alcohol production. According to Michael [44] good table wine alcohol content is between 8 and $14(\%) \mathrm{v} / \mathrm{v}$; of which dried tiger nut wine met that condition.

\subsection{Microbial Analysis of Tiger Nut must during Fermentation}

Figure 9 shows the microbial count of dried and fresh tiger nut must during fermentation process. Results showed a rapid decline in total bacteria count after $48 \mathrm{hrs}$ of fermentation for both fresh and dried tigernut musts. Dried tigernut had initial Total Bacterial Count of 6.61 $\log _{10} \mathrm{CFU} / \mathrm{ml}$ which reduced to $1 \log _{10} \mathrm{CFU} / \mathrm{ml}$ and initial Total Yeast Count of $8.34 \log _{10} \mathrm{CFU} / \mathrm{ml}$ (pitched) which increased to $9.99 \log _{10} \mathrm{CFU} / \mathrm{ml}$, while fresh tiger nut must before fermentation had initial Total Bacterial Count of 6.59 $\log _{10} \mathrm{CFU} / \mathrm{ml}$ which reduced to $1.3 \log _{10} \mathrm{CFU} / \mathrm{ml}$ and initial Total Yeast Count of $8.30 \quad \log _{10} \mathrm{CFU} / \mathrm{ml}$ (pitched) increased to $9.99 \log _{10} \mathrm{CFU} / \mathrm{ml}$ at the end of fermentation. The increase in total yeast count is expected, as yeast have a prominent role in the production of alcoholic beverages, due to the ability to accumulate high levels of ethanol and to produce highly desirable aroma compounds, while the decrease in total bacteria count could be attributed to the production of lactic acid bacteria which are particularly important in fermentation as they were responsible for inhibiting the growth of undesirable organisms to as low as $1 \log _{10} \mathrm{CFU}$ after 7 days of fermentation. Decrease in total coliform count of tigernut wines is in agreement with the result reported by Mountney and Gould, [45], Franzier and Westhoff, [46], Garbutt [47], Adams and Moss [48] for the presence of alcohol, low pH and organic acids. Decrease in total coliform count is in line with the ICMSF [49] recommendation for safe wines. 


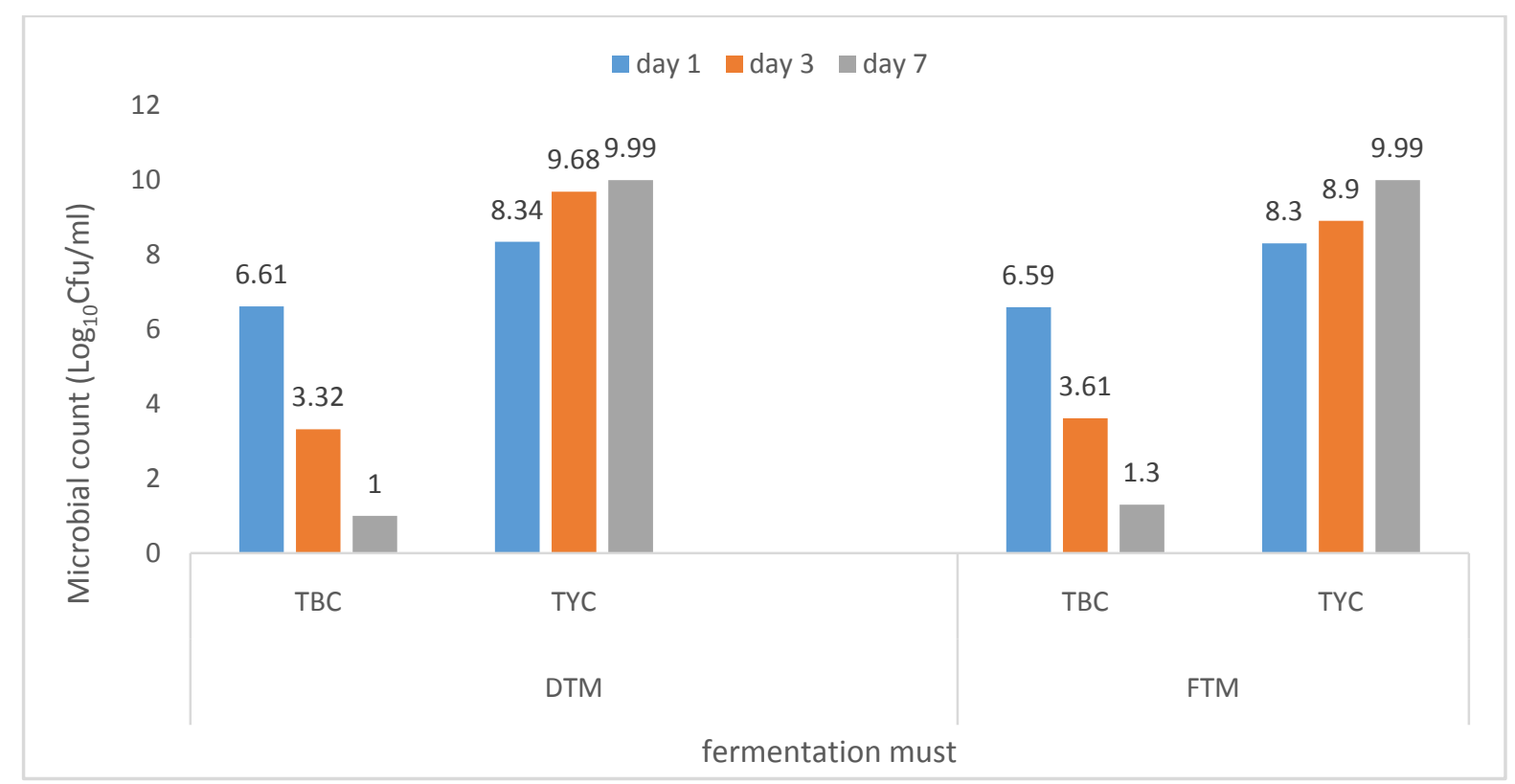

Figure 9. Microbial count of dried and fresh tiger nut must during fermentation process (Keys: TBC $=$ Total Bacterial Count, TYC $=$ Total Yeast Count, DTM $=$ Dried Tigernut Must, FTM = Fresh Tigernut Must)

Table 2. Physicochemical Properties of Tiger nut and commercial grape wine

\begin{tabular}{lccc}
\hline Parameter & $\begin{array}{c}\text { Dried } \\
\text { Tiger } \\
\text { nut wine }\end{array}$ & $\begin{array}{c}\text { Fresh } \\
\text { Tiger } \\
\text { nut wine }\end{array}$ & $\begin{array}{c}\text { (Control) } \\
\text { Commercial } \\
\text { grape wine }\end{array}$ \\
\hline Total soluble solute $\left({ }^{0}\right.$ Brix $)$ & 5.00 & 5.00 & 10.00 \\
$\mathrm{pH}$ & 3.0 & 3.0 & 3.1 \\
Specific gravity & 0.705 & 0.705 & 1.023 \\
Alcohol content $(\% \mathrm{v} / \mathrm{v})$ & 8.19 & 6.41 & 7.50 \\
TTA $(\%)$ & 0.021 & 0.016 & 0.02 \\
\hline
\end{tabular}

Sensory evaluation of commercial grape wine and tigernut wines.

Figure 10 shows the sensory evaluation result of commercial grape and tigernut wines. The results of the sensory analysis of the tigernut wines revealed that the state of the tigernut (fresh or dried) before fermentation affected most of the sensory qualities of the tigernut wines. These qualities were comparable with the commercial grape wine for colour, taste and clarity. For aroma, the commercial grape wine was not significantly different at $(\mathrm{p}<0.05)$ from dried tigernut wine, while overall acceptability of the commercial grape wine was significantly different at $(\mathrm{p}<0.05)$ from the dried and fresh tigernut wines respectively. High scores of preference in aroma, taste and flavour of dried tigernut wine sample may be attributed to drying effect of tigernut tubers which may have brought about a desirable browning reaction on the sensory attributes $[50,51]$.

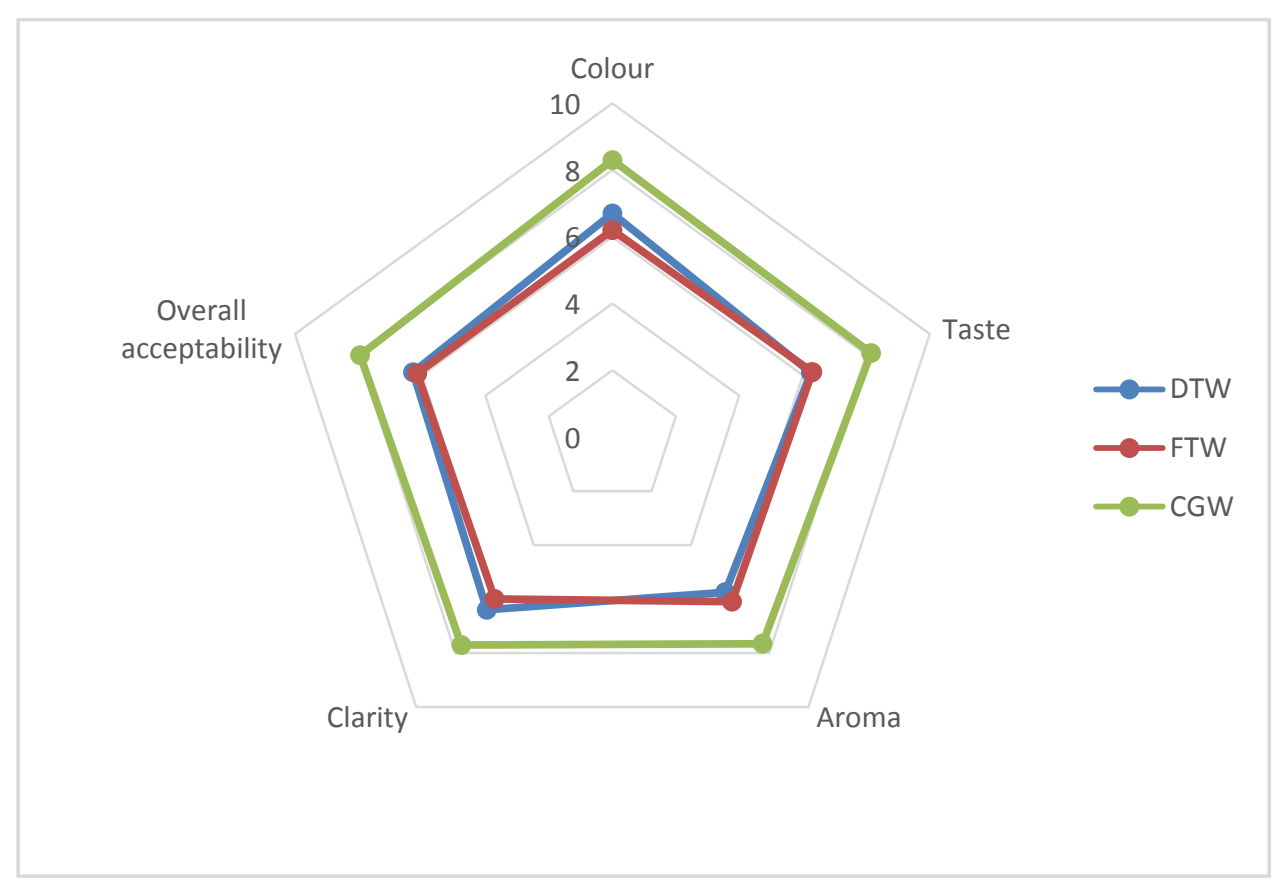

Figure 10. Sensory evaluation of commercial grape wine and tigernut wines (KEYS: FTW= Fresh Tiger nut wine, DTW= Dried Tiger nut wine, CGW= Commercial grape wine (Control)) 


\section{References}

[1] Tariba B., (2011). Metals in wine -impact on wine quality and health outcomes. Biology ofTrace Element and Resource. 144: 143-154.

[2] Baidya, D., Chakraborty, I. and Saha, J. (2016). Table wine from tropical fruits utilizing natural yeast isolates. Journal of Food Science and Technology, 53: 1663.

[3] Lee, P., Saputra, A., Yu, B., Curran, P., and Liu, S. (2012). Biotransformation of durian pulp by mono- and mixed-cultures of Saccharomyces cerevisiae and Williopsissaturnus. Food Science and Technology. 46: 84-90.

[4] Ezeronye, O.U. (2004). Pilando, L. B., Wrolstad, R.E and Heatherbell, DA 1985. Influence of fruit composition, maturity and mold contamination on the color and appearance of strawberry wine. Journal of Food Science. 50: 1121-1125.

[5] Ray R. C., Panda S. K., Swain M. R.andSivakumar S. P (2011) Proximate composition and sensory evaluation of anthocyaninrich purple sweet potato (Ipomoea batatas L.) wine. International Journal of Food Science and Technology. 1365-2621.

[6] Giri N.M.S and Praveen. S.N (2013) Production of wine from Ginger and Indian Gooseberry and a comparative of them over commercial wine. American Journal of Engineering Research. 2(5): 19-38.

[7] Amerine, M.A. Kunkee, R. Ough, K.C.S. Singleton, V.L and Webb, A.D (1980). The technology of wine making (4th Ed). AVI, Westport, Connecticut.pg 185-703.

[8] Shrikant, B. S. Thakor, N.J. andDivate, A.D. (2014) Fruit Wine Production: A Review. Journal of Food Research and Technology 2(3): 93-100.

[9] TTSL (2005). Tigernuts. Chufas. Souchet. Ermandeln. PoisSucrés: Tigernut Traders, S.L. Export www.tigernut.com; http://www.tigernut.com/product3.html/.

[10] Okafor, J.N., Mordi, J.I., Ozumba, A.U., Solomon, H.M. and Olatunji, O. (2003). Preliminary studies on the characterisation of contaminants in tiger nut (yellow variety). In: Proceedings of 27th Annual Conference and General Meeting of Nigerian Institute of Food Science and Technology Kano. Pp.210-211.

[11] FAO (1988).Traditional Food Plants: Food and Nutrition Paper 42 Rome 239-242.

[12] Shaker, M. A., Ahmed, M. G. Amany M. B and Shereen L. N (2009). Chufa Tubers (Cyperus esculentus L.): As a New Source of Food. World Applied Sciences Journal 7 (2): 151-156.

[13] Deatra J. S (1999). Nutsedge: Weedy Pest or Crop of the Future? Southern Illinois University Carbondale / Ethnobotanical Leaflets / http://www.siu.edu/ ebl/

[14] Aliyu, L. (2000). Rosella (Hibiscus sabdariffa L.) production as affected by pruning and sowing date. Applied Agricultural Technology, 6, 16-20.

[15] Osueke, J. C., and Ehirim, F. N. (2004). Chemical, nutritional and sensory analysis of zobo drink (varsabdariffa) and selected soft drinks. Journal of Agriculture and Food Science, 2, 33-37.

[16] Yadeng, Q., Chin, K. L., Malekian, F., Berhane, M., andGager, J. (2005). Biological characteristics nutritional and medicinal values of roselle (Hibiscus sabdariffa). Circular-Urban Forestry Natural Resources and Environmental, 604, 1-2.

[17] Ali-Bradeldin, H., Al-Wabel, N., \&Gerald, B. (2005). Phytochemical pharmacological and toxicological aspects of Hibiscus sabdariffa: A review. Journal of Phytotherapy Research, 19, 369-375.

[18] Juliani, H. R., Welch, C. R., Wu, Q., Diouf, B., Malainy, D., and Simon, J. E. (2009). Chemistry and quality of hibiscus (Hibiscus sabdariffa) for developing the natural-product industry in Senegal. Journal of Food Science, 74, (113-121).

[19] Ezearigo, O. E., Adeniyi, P. O., andAyoade, F. (2014). Screening of natural spices for improving the microbiological, nutritional and organoleptic qualities of the 'zobo' drink. Journal of Applied Biosciences, 76, 6397-6410.

[20] Mohamad, O., Mohd-Nazir, B., Abdul Rahman, M., and Herman, S. (2004). Roselle: A new crop in Malaysia. Buletin PGM, 8, $12-13$.

[21] Al-Hashimi, A. G. (2012). Antioxidant and antibacterial activities of Hibiscus Sabdariffa L. extracts. African Journal of Food Science, 21, 506-511.
[22] Mohamed, R., Fernández, J., Pineda, M., andAguilar, M. (2007). Roselle (Hibiscus sabdariffa) seed oil is a rich source of $\gamma$-tocopherol. Journal of Food Science, 72, 207-211.

[23] Egbere, O. J., Anuonye, J. C., Chollom, P. F., andOkpara, P. V. (2007). Effects of some preservation techniques on the quality and storage stability of zobo drink (A Nigerian, non-alcoholic beverage from Hibiscus sabdariffa). Journal of Food Technology, $5,225-228$

[24] Coskuner, Y.C., Ercan, R. and Karababa, E. (2002). Chemical properties of chufaCyperusesculentus L.) tubers found in the Cukurova region of Turkey. Journal Science of Food and Agriculture, 82: 625-631.

[25] Rita, E.S. (2009). The use of tiger nut (Cyperus esculentus), cow milk and their composite as substrate for yoghurt production. Pakistan Journal of Nutrition. 6:755-758.

[26] Amerine, M.A, and Kunkee, R.E (2002). Microbiology of Wine Making. Annual Review onMicrobiology. 2: 232-258.

[27] Robinson, J. (2006). The Oxford Companion to Wine. Oxford University Press, New York. Ruf, J.C. (2003). Overview of epidemiological studies on wine, health and mortality. Drugs Exp. Clinical Resource. 29: 173-179.

[28] AOAC (2005). Official Methods of Analysis ( $22^{\text {nd }}$ Edition). Association of Official Analytical Chemists. Washington USA.

[29] Ogu, E. O, and Mgbebu, P. O. (2011). Foundation for African development trough international biotechnology (FADIB), 19: 49-53.

[30] Harrigan, W.F. (1998). Laboratory methods in Microbiology Academics Press, Califonia, USA.

[31] Cheesbrough, M. (2000). Water-related diseases and testing of water diseases lies in District Laboratory Practice in Tropical Countries. Part 2 (LP. Ed). Cambridge University Press, Cambridge, U.K. Pp 143-157

[32] Iwe, M.O. (2002). Handbook of sensory methods and analysis. Enugu, Nigeria: Rojoint Communications. Services Limited; p. 14.

[33] Fleet, G.H (2013). Yeast interaction and wine flavor. International Journal of Food Microbiology. 86: 11-22.

[34] Reddy, L.V, Reddy, O.V.,S (2005) Production and characterization of wine from mango fruit (Mangiferaindica). World Journal of Microbiology and Biotechnology. 21: 1345-1350.

[35] Abbo ES, Olurin T, Odeyemi G (2006). Studies on the storage stability of soursop (AnnonaMuricataL.) juice. African Journal of Biotechnology 5: 108-112.

[36] Bisson, L. F., and Butzke, C. E.,. (2007). The role of moderate ethanol consumption in health and human nutrition. American Journal of Enology and Viticulture, 48: 449-460.

[37] Ndubuisi L. C. (2009). Evaluation of food potentials of tigernut tubers (cyperus esculentus) and its products (milk, coffee and wine). Dissertation. Department of Home Science, Nutrition and Dietetics, University of Nigeria, Nsukka.

[38] Ogodo, A. C., Ugbogu, O. C., Ugbogu, A. E. and Ezeonu, C. S. (2015). Production of mixed fruit (pawpaw, banana and watermelon) wine using Saccharomyces cerevisiae isolated from palm wine. Springer Plus, 4:683.

[39] Akingbala, J.O. Oguntimein, G.B. Olunlade, B.A and Aina, J.O (1992). Effects of pasteurization and packaging on properties of wine from over-ripe mango (Mangiferaindica) and banana (Musaacuminata) juices. Tropical Science, 34: 345-352.

[40] Liga, P and Diana, K (2014). Determination of mahor sugars in fresh and dried spices and vegetables using high performance liquid chromatography. In: $9^{\text {th }}$ Baltic Conference on Food Science and Technology, Conference Proceedings Food Balt. p(198-201).

[41] Keller, J.B (2010). Pineapple Wine: Directions for Pineapple Wine Baskets; Available from: http://www.ehow.com/way_5810589_direction-pineapplewinebaskets.html\#ixzz14iXAYA5s. Last accessed on Nov 16 2010.

[42] Akubor P. I (1996). The suitability of African bush mango juice for wine production. Plant Foods for Human Nutrition 49:213-219.

[43] Jack, B.K. (2007). Wine Making. Retrieved from http://www.Jack keller.net.

[44] Micheal, P., (2000). Foods of the Gods: Part 1-Wine in Ancient Egypt. Retrieved from: http:/www.touregypt.net/Egypt-info/magazine-meg11012000magf.htm. (Accessed: August 12, 2010). 
[45] Mountney, G. J. and Gould, W. A. (1988). Practical Food Microbiology and Technology. AVI Books, Van Nostrand Reinhold Company, New York, USA.

[46] Frazier, W. C and Westhoff (1978). Food microbiology. $3^{\text {rd }}(\mathrm{Ed})$ mc Gram Hill pub.co. New Delhi Tata Nutrient utilization profile of Saccharomyces Cerevisiae from palm wine in tropical fruit fermentation. Antonie Van Leeuwenhoek 86: 235

[47] Garbutt, J. (1997). Essentials of Food Microbiology; Arnold Publishers. P (103-245).
[48] Adams, M.R. and Moss, M. O., (1995). Food Microbiology. The Royal Society of Chemistry, Cambridge, UK.

[49] ICMSF (1996).Toxigenic fungi: Aspergillus. In: Microorganisms in Foods. 5. Characteristics of Food Pathogens Academic Press, London, Pp. 347-381.

[50] Bender, A. E. (1973). Nutrition and Dietetic Foods: $2^{\text {nd }}$ ed. Chemical Publishing Co. Inc. Newyork.

[51] Lake and Waterworth (1983) Munn Rankin and Hildreth"s Foods and nutrition 13thed. Bell and Hyman Ltd London Pp 358-367.

(C) The Author(s) 2019. This article is an open access article distributed under the terms and conditions of the Creative Commons Attribution (CC BY) license (http://creativecommons.org/licenses/by/4.0/). 